\title{
Bat Populations and Cave Microclimate Prior to and at the Outbreak of White-Nose Syndrome in New Brunswick
}

\author{
Karen J. Vanderwolf ${ }^{1,3,4}$, Donald F. McAlpine ${ }^{1,2}$, Graham J. Forbes $^{2}$, and David Malloch ${ }^{1}$ \\ ${ }^{1}$ New Brunswick Museum, 277 Douglas Avenue, Saint John, New Brunswick E2K 1E5 Canada \\ ${ }^{2}$ Biology Department, University of New Brunswick, Fredericton, New Brunswick E3B 6E1 Canada \\ ${ }^{3}$ Current address: Canadian Wildlife Federation, 350 Promenade Michael Cowpland, Kanata, Ontario K2M 2W1 Canada \\ ${ }^{4}$ Corresponding author email: karenv@cwf-fcf.org
}

\begin{abstract}
Vanderwolf, Karen J., Donald F. McAlpine, Graham J. Forbes, and David Malloch. 2012. Bat populations and cave microclimate prior to and at the outbreak of white-nose syndrome in New Brunswick. Canadian Field-Naturalist 126(2): 125-134.

Information on bat populations and hibernacula is important for understanding the impacts of white-nose syndrome (WNS), a fatal fungal disease of bats. Estimates of bat populations prior to the outbreak of white-nose syndrome are presented for 2009-2011 for the most significant bat hibernacula known in New Brunswick. At one of these sites we recorded a major mortality event from white-nose syndrome, the first in the Maritime provinces, late in the winter of 2011. Winter surveys of hibernating bats suggest that a minimum of 7000 bats overwintered in these hibernacula prior to the outbreak of white-nose syndrome in New Brunswick. The majority of hibernating bats in New Brunswick caves are Myotis lucifugus (Little Brown Myotis) and M. septentrionalis (Northern Myotis), with low numbers of Perimyotis subflavus (Tricolored Bat). The New Brunswick hibernacula that support the greatest numbers of overwintering bats have little temperature variation, winter dark zone temperatures averaging $4-5^{\circ} \mathrm{C}$, and minimum dark zone temperatures dropping to no lower than $3.1^{\circ} \mathrm{C}$. New Brunswick caves with these temperature patterns characteristically have $\geq 140 \mathrm{~m}$ of main passage and lack both running water and multiple entrances. Few cave sites in the province meet these criteria, and the known winter bat population appears to be smaller than the summer population. Many bats present during the summer in New Brunswick either hibernate in unknown locations in the province or migrate out of the province to locate suitable hibernacula. Such movements may have hastened the arrival of white-nose syndrome in New Brunswick.
\end{abstract}

Key Words: Myotis lucifugus, Little Brown Myotis, Myotis septentrionalis, Northern Myotis, Perimyotis subflavus, Tricolored Bat, white-nose syndrome, cave, microclimate, hibernation, temperature, New Brunswick.

White-nose syndrome (WNS) is a lethal fungal disease affecting cave-dwelling North American bats that was first identified in 2006 in New York (Blehert et al. 2009). The disease affects bats during the hibernation period, and the high mortality rate is predicted to lead to the regional extinction of some bat species (Frick et al. 2010). In eastern Canada, a full understanding of white-nose syndrome is hindered by lack of information on the size of bat populations prior to the outbreak of white-nose syndrome, the locations of hibernacula, and the features that characterize cave and mine sites occupied by bats during the winter. Such information can help support efforts to better understand how whitenose syndrome is spread, allow the magnitude of bat mortality to be assessed, and assist investigators in determining whether the physical characteristics of hibernacula influence the ecology or impact of whitenose syndrome.

Surveys of New Brunswick bat hibernacula have not been conducted for more than 25 years (McAlpine 1983), and initial surveys were relatively superficial. Although there are approximately 25 natural solution caves in New Brunswick (McAlpine 1983; Arsenault et al. 1997), less than half of these are apparently suitable as bat hibernacula. Most of the known hibernacula in Nova Scotia and New Brunswick rarely contain more than a few hundred bats (Moseley 2007a). The largest known concentration of hibernating bats in the Maritime provinces occurs in Hayes Cave, Nova Scotia, where approximately 10000 bats, mainly Myotis spp., have been recorded (Moseley 2007a).

No studies on the environmental conditions of New Brunswick caves have previously been undertaken. The temperature of the dark zone (zone of no light penetration) in Frenchman's Cave in Nova Scotia has been recorded to range from approximately 4 to $8^{\circ} \mathrm{C}$ annually (Moseley 2007b). In contrast, the dark zone temperatures of some large European caves varies by 0.1-0.5 Celsius degrees over the course of the year (Hoyos et al. 1998; Laiz et al. 2003; Jurado et al. 2010). Although the data are limited, none of the Nova Scotia caves studied by Moseley (2007b) maintained a constant temperature in the dark zone (the temperature range was approximately 4 Celsius degrees over the year), due to relatively short passage length, the presence of running water, or air flow associated with multiple entrances (Moseley 2007b). New Brunswick caves are similar in structure to the Nova Scotia caves studied by Moseley (2007b) and on this basis they would be expected to show similar temperature patterns.

In 2009, in anticipation of the spread of white-nose syndrome to New Brunswick, we initiated a project to survey bat populations at known hibernacula and to characterize the microclimate in these sites. Here we 


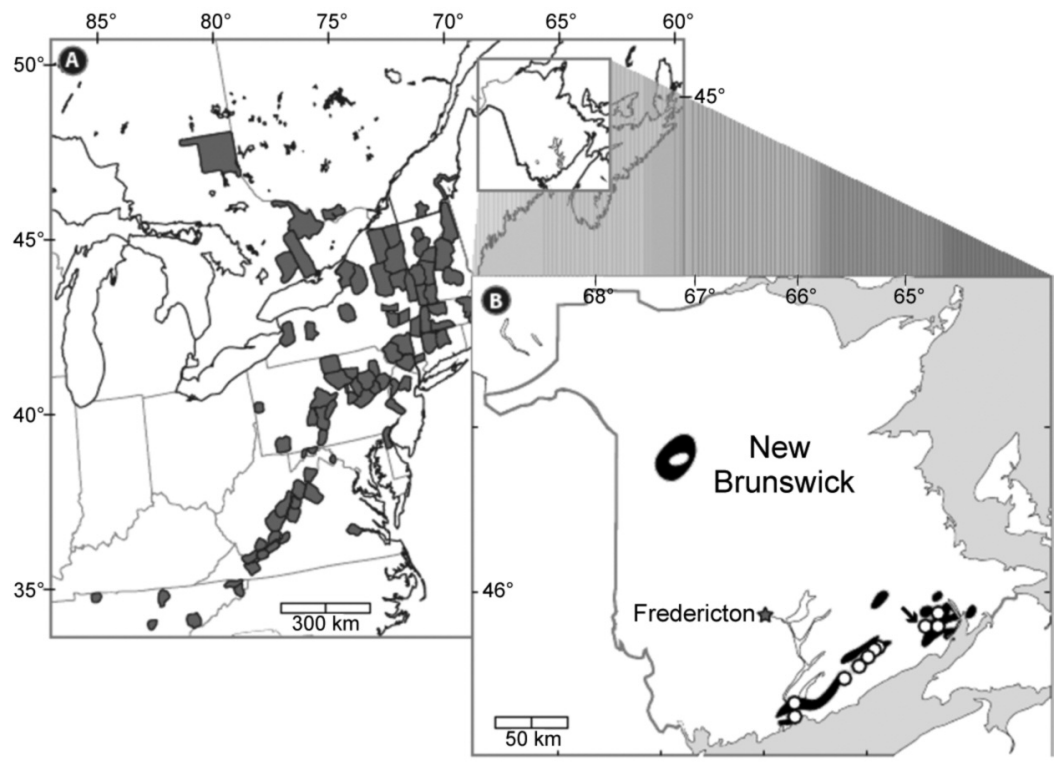

FIGURE 1. A) Grey-shaded polygons indicate state and provincial counties or districts in eastern North America where white-nose syndrome had been confirmed or suspected up to the winter of 2009-2010, based on United States Fish and Wildlife Service data, and prior to its spread into New Brunswick. Three suspected sites, west of the map region shown, are not included. B) The location of the 10 caves and mines surveyed for bats in New Brunswick during the study (open circles). An arrow marks the Berryton Cave site. Black areas show the limited areas of limestone and gypsum in New Brunswick where natural solution caves might develop.

present data on bat numbers at all known New Brunswick hibernacula prior to the outbreak of white-nose syndrome and incorporate data from the outbreak of white-nose syndrome in the province. We also compare data on the microclimate of New Brunswick caves and mines, focusing on those used as hibernacula, to correlate bat abundance with cave environmental features.

\section{Study Area and Methods}

Eight caves and two abandoned manganese mines in southern New Brunswick, including all of the most significant bat hibernacula known in the province, were selected for study (McAlpine 1983) (Figure 1). The caves are natural solution caves (i.e., have developed in limestone and gypsum bedrock). There are few areas of New Brunswick with geology that will support the formation of natural solution caves (Figure 1), and the number of abandoned mines suitable as bat hibernacula appears to be limited (Cory Neumann, Minerals and Petroleum Development Branch, New Brunswick Department of Natural Resources, personal communication to DFM). The dimensions of the caves and one of the mines were previously mapped by McAlpine (1976, 1982, 1983) and Arsenault et al. (1997). Unless stated otherwise, our use of the word "cave" includes both natural solution caves and abandoned mines.

Generally, a single visit per cave per year, in the latter half of the winter hibernation period ("winter" is here defined as 1 November to 30 April), was undertaken to count bats. We did not distinguish between Myotis spp., since most bats were roosting beyond our reach and we wished to minimize disturbance to those hanging lower down on vertical surfaces. However, Perimyotis subflavus, Tricolored Bat, could be identified without handling on the basis of size, coloration, and roosting habits. Visits were kept to a minimum because hibernating bats will arouse even with nontactile human disturbance (e.g., light and sound), and repeated disturbance can lead to increased bat mortality (Thomas 1995). Although at the outset of this work and through 2010 all evidence suggested that white-nose syndrome was not present in the region, all survey participants followed the United States Fish and Wildlife Service protocol to minimize the spread of white-nose syndrome (U.S. Fish and Wildlife Service 2009) when visiting multiple caves.

Bat abundance was estimated based on the mean of independent counts by two to four individuals each using hand-held tally counters. Photography of roosting bats, although initially attempted as a census method (Meretsky et al. 2010), was not found to be practical, since bats were relatively few in number $(<300$ at most sites), were often widely dispersed in the hibernacula (clusters of $<50$ bats), or were in passages where photography was not possible (i.e., high on vertical walls in narrow passages). Only live bats were counted, 
with the exception of Berryton Cave in 2011, when both live and recently dead bats were counted. Counts were conducted between January 2009 and March 2011.

Temperature/humidity logger iButtons (model DS1923-F5, Maxim Integrated Products, Inc., Sunnyvale, California) were placed in the caves in the fall of 2009 and retrieved in the fall of 2010. iButtons were set to record air temperature and relative humidity twice a day (at 0230 and $1430 \mathrm{hrs}$.). Two iButtons were deployed in each cave: one was placed $1-2 \mathrm{~m}$ from the ground on a wall ledge in the twilight zone (i.e., the entrance area where some light penetrates) and the other was placed under similar circumstances in the dark zone.

iButtons in the dark zone were placed in passage or chamber areas where bats roosted (if bats were present) at distances $>1 \mathrm{~m}$ from roost sites to minimize disturbance. Willis et al. (2009) reported that iButtons may emit ultrasonic frequencies that may disturb hibernating bats. iButtons in the dark zone were $45 \mathrm{~m}$ (SD 26) from the entrance, with placement depending on the length of the cave and the location of hibernating bats. iButtons in the twilight zone were placed $7 \mathrm{~m}$ (SD 5) from the entrance.

Temperature and bat count data were not normally distributed, even with transformation. Therefore, a Mann-Whitney test was used to determine whether there were significant differences in average winter temperature in caves with and without hibernating bats. An $F$-test was used to test for differences in winter temperature variation (calculated as the maximum winter temperature minus the minimum). Spearman's rank order correlation $(R)$ was used to determine whether bat abundance was correlated with cave length, average winter cave temperature, minimum temperature, or winter temperature variation. A Mann-Whitney test was used to determine whether bat abundance differed between caves with and without running water (i.e., active stream through the cave).

\section{Results}

Bat counts in hibernacula

A total of 1988 bats were counted in 2010 and 7076 in 2011. Data for 2009 were incomplete and preliminary, but they produced numbers similar to those recorded in 2010. The large increase in bat numbers in 2011 was due to behavioural changes in bats associated with the outbreak of white-nose syndrome in Berryton Cave (McAlpine et al. 2011); both live and recently dead bats are included in the total for this cave (Table 1). In March 2011, many bats in Berryton Cave were found to be infected with Geomyces destructans. We found large numbers of bats roosting low on the walls near the cave entrance, many of them in an area of highly variable temperature where ice was present. This behaviour, known to be associated with white-nose syndrome (Turner et al. 2011; Langwig et al. 2012), placed bats in easily visible locations and facilitated counting. Bats were not observed overwintering in these areas of Berryton Cave in 2009, 2010, at the outset of the 2011 hibernation period, or in previous decades (DFM, unpublished data). Berryton Cave has narrow, high ( $\geq 7 \mathrm{~m}$ ) passages (Figure 2), some of which are inaccessible to investigators. We believe this is where significant numbers of bats were roosting in the March 2010 count and the October 2009 and 2010 visits. Excluding Berryton Cave data, there was no significant difference between bat counts in 2010 and $2011(P=0.475)$.

More than $99 \%$ of bats counted were Myotis lucifugus or M. septentrionalis. No Eptesicus fuscus (Big Brown Bat) were observed. A small number of Tricolored Bats were observed in Markhamville Mine $(n=9$; February 2010), Glebe Mine $(n=5$; February 2010), Berryton Cave ( $n=2$; March 2010), White Cave $(n=3$; March 2010), Dalling's Cave $(n=1$; November 2009), and Underground Lake Cave ( $n=1$; March 2010). All $P$. subflavus were observed hibernating individually (i.e., not clustered, as Myotis spp.) and low on the cave walls. This tendency of $P$. subflavus to hibernate individually has also been observed in caves in Ontario (Hitchcock 1949), Missouri (Guthrie 1933), Arkansas (Briggler and Prather 2003), and Florida (McNabb 1974).

\section{Cave temperatures}

Due to apparent high humidity in caves, iButton humidity readers malfunctioned and no reliable humidity data were obtained.

The average annual air temperature of our study caves, using both twilight and dark zone data, was $5.5^{\circ} \mathrm{C}$ (SD 1.6) for hibernacula and non-hibernacula sites combined $(n=9)$ and $5.2^{\circ} \mathrm{C}(\mathrm{SD} 2.1)$ for hibernacula only $(n=7)$. These temperatures approximate the average annual above ground air temperature in southern New Brunswick, where these caves are located (annual average from 1971 to 2000 was $5.1^{\circ} \mathrm{C}$ (SD 0.8) (Environment Canada 2011*). The average annual dark zone air temperature was $6.0^{\circ} \mathrm{C}$ (SD 1.3) for all caves and $5.9^{\circ} \mathrm{C}$ (SD 1.4) for hibernacula only. The average dark zone air temperature in non-hibernacula $(n=2)$ during winter when bats were present was $3.8^{\circ} \mathrm{C}$ (SD 2.1), which was not significantly colder than in hibernacula $\left(5.1^{\circ} \mathrm{C}\right.$, SD $1.1, n=6, W=29$, $P=0.617$ ). Also, air temperature in hibernacula was not significantly less variable than in non-hibernacula $(F=0.31, P=0.263)$. The average dark zone air temperature during winter in mines $\left(5.8^{\circ} \mathrm{C}, \mathrm{SD} 1.2, n=2\right)$ was warmer than in caves $\left(4.8^{\circ} \mathrm{C}, \mathrm{SD} 1.0, n=4\right.$ hibernacula only; $4.5^{\circ} \mathrm{C}, \mathrm{SD} 1.4, n=6$ (all caves)).

As expected, the air temperature in the twilight zone in all caves was more variable than in the dark zone (Figure 3). During winter, air temperatures in the dark zone were higher than in the twilight zone. Those caves with the largest number of bats (Berryton, White, Underground Lake, and Markhamville) showed the least amount of fluctuation in the dark zone air temperature (compared to the other caves). All of these sites had approximately the same mean dark zone winter air temperature $\left(4.7^{\circ} \mathrm{C}, \mathrm{SD} 0.7\right)$ (Figure 4$)$. 


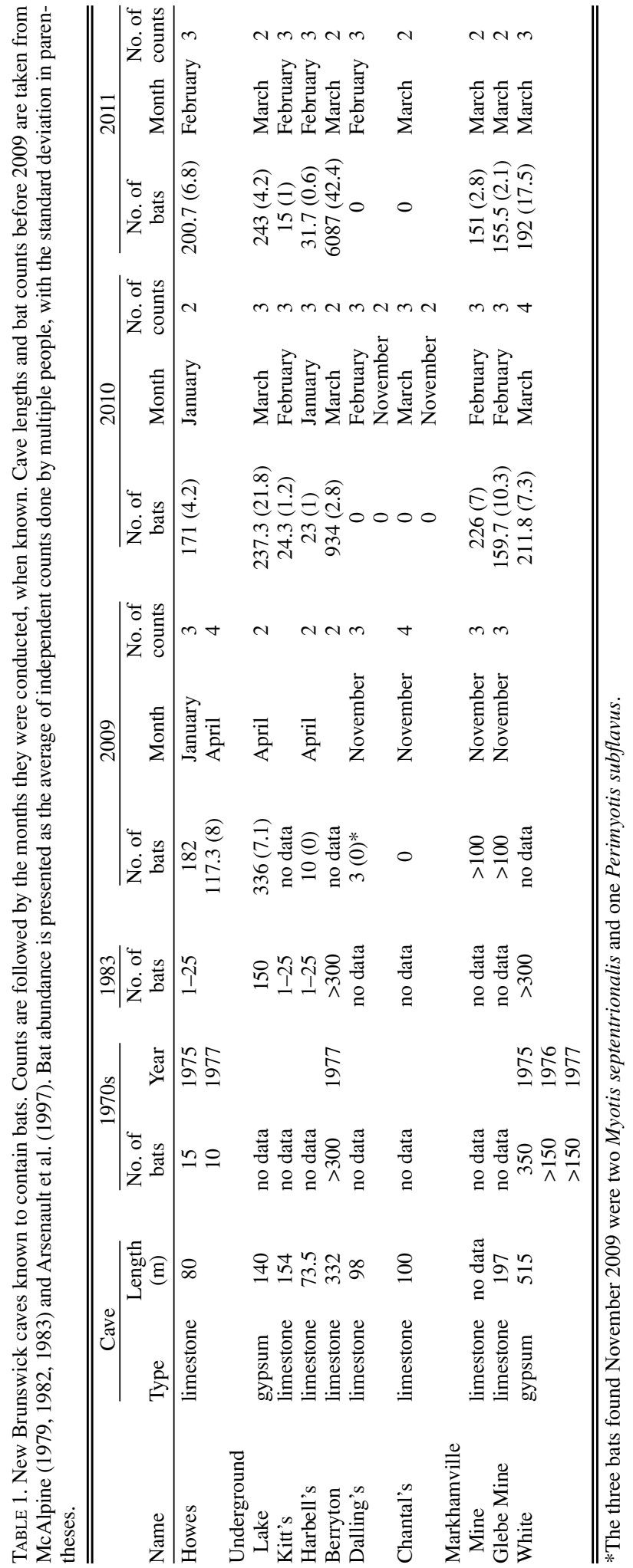




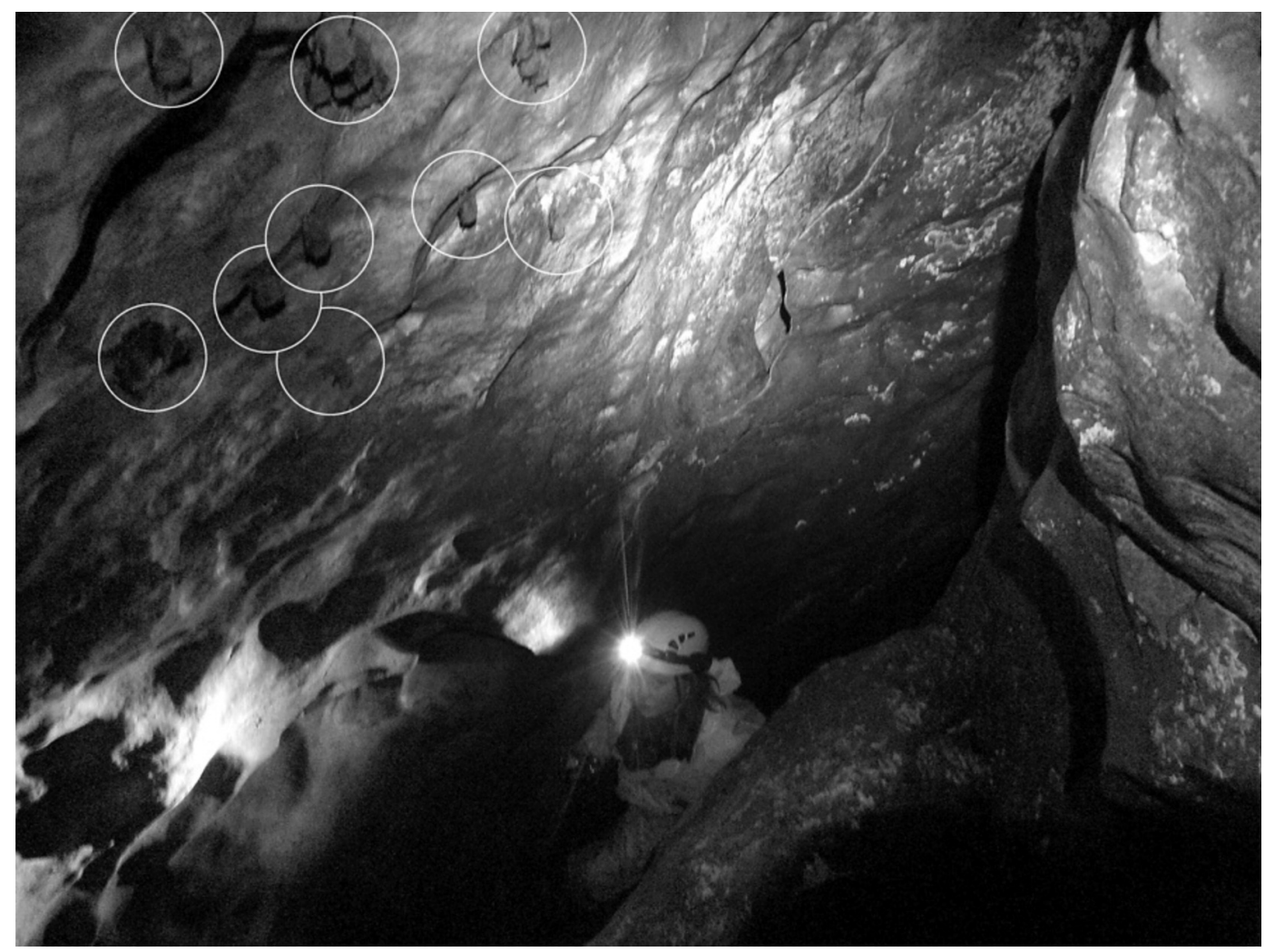

FIGURE 2. Myotis spp., both individuals and clusters, can be seen roosting high on the left wall of Berryton Cave, New Brunswick. Circles mark a total of 22 bats. Narrow passages that gradually become restricted as they reach a height of as much as $7 \mathrm{~m}$ make it difficult to count bats at this site. Photo: DFM, 14 December 2011.

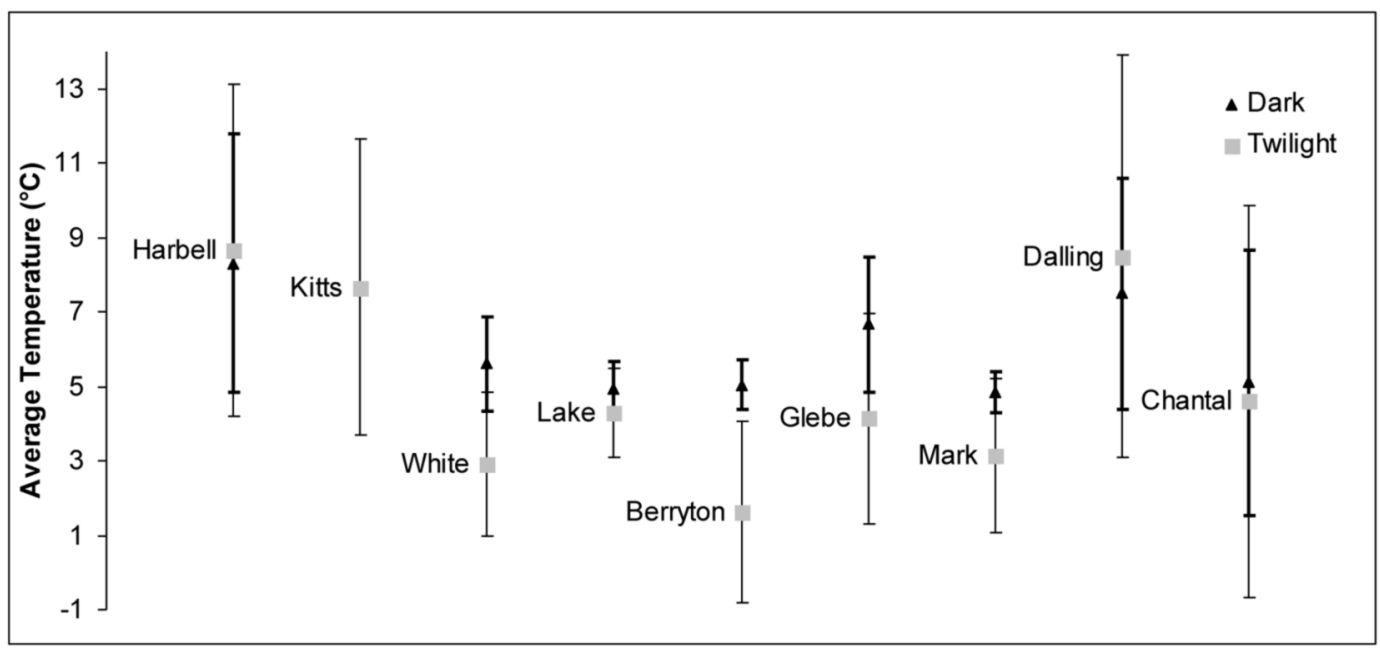

FIGURE 3. Average temperature (SD) of surveyed New Brunswick caves over a one-year period from November 2009 to November 2010. Dark and Twilight refer to the locations of the data loggers within the cave. Mark = Markhamville Mine, and Lake = Underground Lake Cave. Hibernating bats were not recorded in Dalling's or Chantal's caves. Dark zone data were not available for Kitt's Cave. 


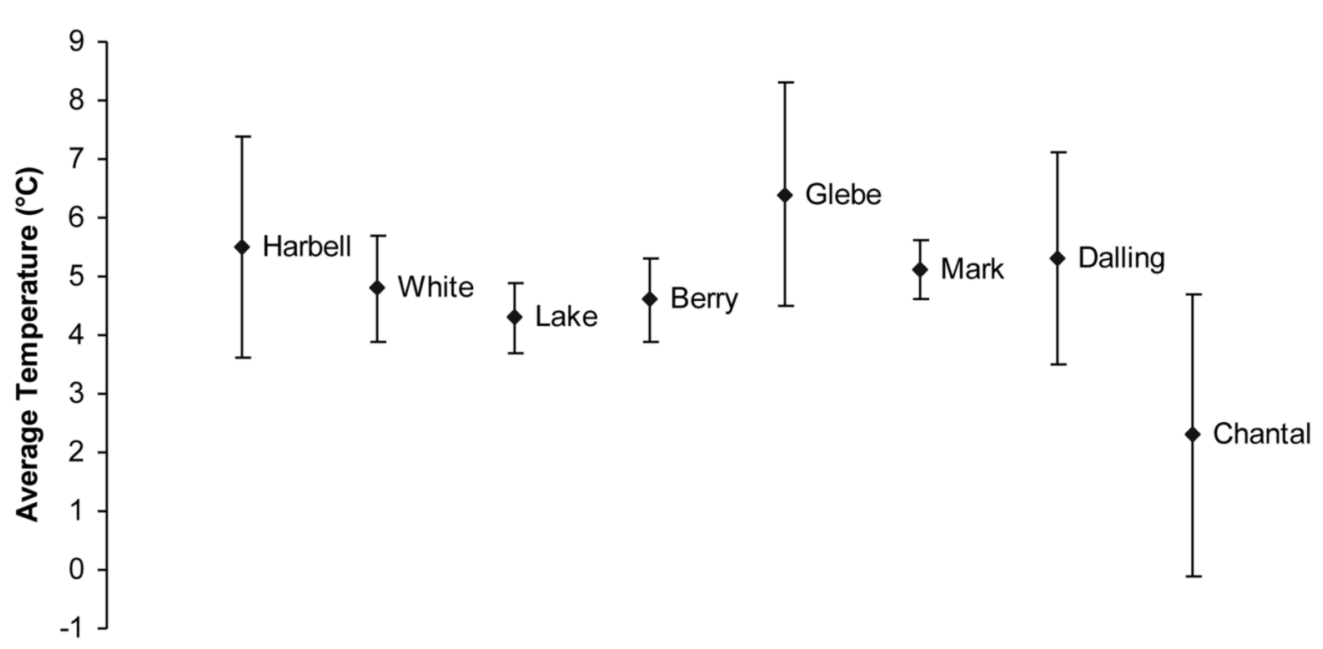

FIGURE 4. The average dark zone temperature (SD) of New Brunswick caves during the winter (1 November 2009 to 30 April 2010) when bats are present. Dalling's and Chantal's caves did not harbor bats. Data for Kitt's Cave were unavailable. Mark = Markhamville Mine, Lake $=$ Underground Lake Cave, and Berry = Berryton Cave.

The dark zone temperature of Berryton Cave, the New Brunswick hibernaculum harbouring the largest number of bats, was particularly stable. When the iButton was first deployed in Berryton Cave on 6 October 2009 , a temperature of $5.6^{\circ} \mathrm{C}$ was recorded twice a day until 8 December 2009, when the temperature gradually began to fall to a low of $3.1^{\circ} \mathrm{C}$ at the beginning of February. The temperature reached $5.6^{\circ} \mathrm{C}$ again on 6 July 2010 and remained constant until the iButton was removed on 8 October 2010.

The resistance of Markhamville Mine to outside climatic influence is also notable. This site demonstrated the longest lag time in responding to outside seasonal temperature changes. Markhamville Mine reached its minimum dark zone temperature $\left(4.1^{\circ} \mathrm{C}\right)$ on 22 April 2010 and remained at that temperature until 24 July 2010. Maximum temperature in Markhamville Mine was reached on 21 November 2010, while the other caves reached maximum temperatures in early September or early October. Generally, caves reached their minimum temperatures in early February (lowest average temperatures in March) (Figure 5). The magnitude of temperature variation was smallest in late winter/ early spring and greatest in the fall.

No hibernating bats were recorded in Chantal's Cave; this was the only cave site where air temperatures below $0^{\circ} \mathrm{C}$ in the dark zone were recorded (Figure 6). Although three bats were found in Dalling's Cave in November 2009, we do not believe this site is routinely used as a hibernaculum (one freshly dead Myotis septentrionalis was recorded in Dalling's Cave in February 2010). These two sites had the greatest dark zone winter air temperature ranges, from 2.6 to $9.1^{\circ} \mathrm{C}$
(Dalling's) and -2.9 to $8.1^{\circ} \mathrm{C}$ (Chantal's) (higher maximum temperatures shown in Figure 6 were reached during the summer). The winter air temperature in the hibernaculum with the greatest dark zone winter air temperature range, Harbell's Cave, varied from 3.6 to $9.6^{\circ} \mathrm{C}$. While the winter air temperature range in Harbell's Cave was almost as great as in Dalling's Cave, the minimum dark zone temperature of $3.6^{\circ} \mathrm{C}$ in Harbell's Cave appears to be high enough that small numbers of bats can successfully overwinter at this site.

Only bat abundance data collected in 2010 were used in our analysis of factors characterizing hibernacula. Data collected in 2009 were preliminary and missing from most sites. By 2011, white-nose syndrome was present in the study area and had clearly affected bat behaviour at the one cave where it was detected (McAlpine et al. 2011).

Bat abundance was not correlated with cave length ( $R=0.577, P=0.104)$, minimum dark zone temperature $(R=0.341, P=0.408)$, or average dark zone winter temperature $(R=-0.252, P=0.548)$, but it was negatively correlated with dark zone winter temperature variation $(R=-0.898, P=0.002)$. When non-hibernacula were excluded from the analysis, bat abundance was negatively correlated with average dark zone winter temperature $(R=-0.854, P=0.031)$ but not with minimum dark zone temperature $(R=-0.598, P=0.210)$. Caves without running water $(n=6)$ had significantly more bats than caves with running water $(n=4)(W=$ $45.0, P=0.014)$. However, these environmental variables are not independent of each other. The presence of running water in a cave significantly increases the temperature variation $(W=15, P=0.037)$. 


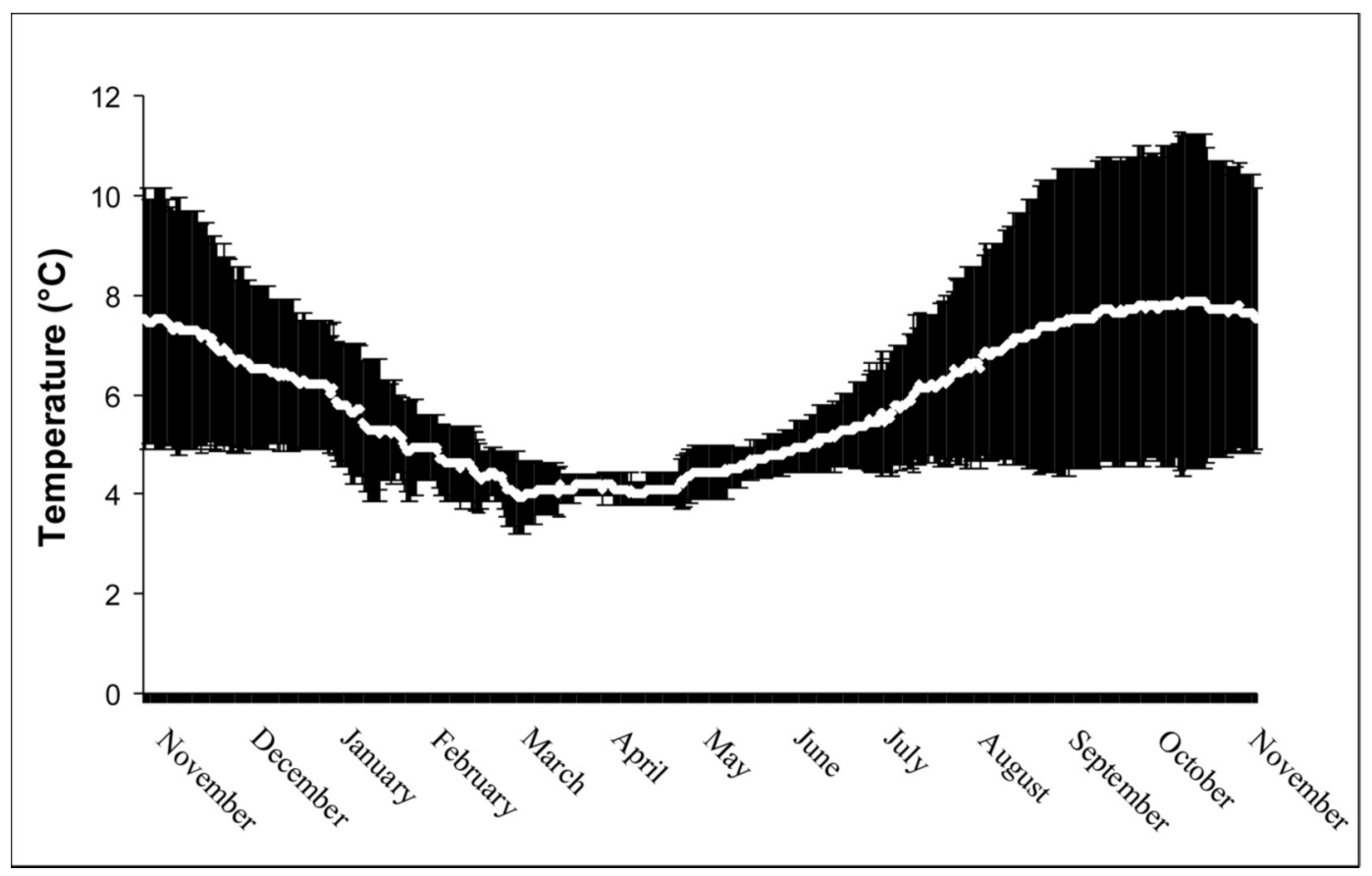

FIGURE 5. The combined average dark zone temperature (SD) in seven New Brunswick caves used as bat hibernacula over a one-year period (November 2009 to November 2010).

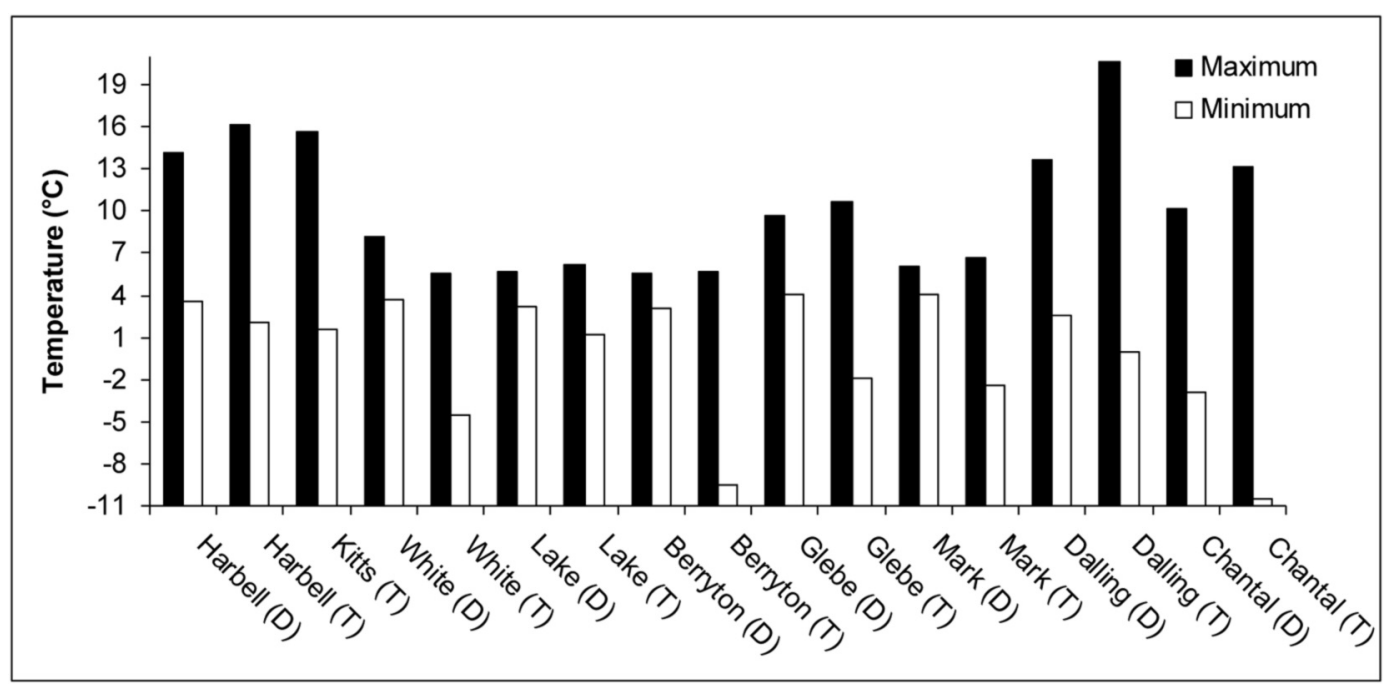

FIGURE 6. The maximum and minimum temperatures of New Brunswick caves over a one-year period from November 2009 to November 2010 in the dark zone (D) and the twilight zone (T). Mark = Markhamville Mine and Lake = Underground Lake Cave. 


\section{Discussion}

It appears that the number of bats in Berryton Cave was drastically underestimated in 2010. Counts for other caves that were not infected with white-nose syndrome are generally consistent across years, and we believe they provide a reliable index of bat numbers. The structure of the passages in these caves does not suggest large numbers of bats were uncounted. This is confirmed by data collected at these hibernacula in 2012 subsequent to this study (in preparation). Even where white-nose syndrome was present and bat behaviour had changed (winter 2012), we did not record the kind of dramatic increases in bat numbers that we did in Berryton. While the number of bats counted may not reflect the absolute number of bats present, consistency suggests that such counts at some sites may be useful in the long-term monitoring of bat populations.

The maximum number of overwintering bats we counted in New Brunswick was $\sim 7000$ in 2011. This is half the size of the total known overwintering population of Myotis lucifugus in Nova Scotia ( 15 000; Scott and Hebda 2004). There are no summer bat population estimates for New Brunswick, but the summer population of M. lucifugus in Nova Scotia has been estimated at 300000 (Scott and Hebda 2004). New Brunswick has $71450 \mathrm{~km}^{2}$ of land area and Nova Scotia has $53338 \mathrm{~km}^{2}$ (Statistics Canada 2005*) with similar habitat types (Davis and Browne 1996; Zelazny 2007). Extrapolating from the figures in Scott and Hebda (2004), we believe New Brunswick may support numbers of $M$. lucifugus during the summer months equal to or greater than the number in Nova Scotia.

Several North American studies have noted that known winter populations of cave-dwelling bats are smaller than summer populations (Griffin 1945; Hitchcock 1949; Davis 1959). It is possible that bats may hibernate in rock crevices and caves unknown and inaccessible to investigators. In a Colorado radio-tracking study, Neubaum et al. (2006) found Big Brown Bats hibernating in rock crevices. It is worth adding, however, that this species is noted for its tolerance of low temperatures. Also, a portion of the summer bat population in the Maritimes may possibly overwinter elsewhere, such as the northeastern United States, where suitable hibernacula are more abundant (Wilson 2009*).

Given the prevalence of white-nose syndrome in the northeastern U.S., such migrations may have hastened the spread of white-nose syndrome to the Maritimes. Wilder et al. (2011) found that caves with many bats $(>1000)$ were the first to be affected by white-nose syndrome. This pattern was observed in New Brunswick; Berryton Cave bat counts were well above those of other caves in the province, even before white-nose syndrome was detected at this site.

The average annual air temperature of all New Brunswick caves studied $\left(5.5^{\circ} \mathrm{C}, \mathrm{SD} 1.6\right)$ is similar to that reported for caves in central Nova Scotia $\left(\sim 5.7^{\circ} \mathrm{C}\right)$ (Moseley 2007b). Generally, temperatures in the dark zone of caves worldwide closely approximate the mean annual temperature of the surrounding region (Dwyer 1971).

The stability of the temperature observed in Berryton Cave, Markhamville Mine, and Underground Lake Cave can be attributed to a combination of the length of the cave and the entrance structure. Caves with vertical or inclined entrances act as cold air sumps, which improve the environment for hibernation by lowering the temperature and reducing temperature fluctuations (Daan and Wichers 1968). Berryton Cave has a narrow vertical entrance, Markhamville Mine has a narrow inclined entrance with a sustained deepening of the passages beyond it, and Underground Lake Cave has a large but deeply inclined entrance. The large body of stationary water in Underground Lake Cave (groundwater fed) may also help moderate temperatures at this site.

The temperature variability in Harbell's, Dalling's, Kitt's, and Chantal's caves is the result of the presence of an active stream in each of these caves during the hibernation period. The streams passing through Harbell's and Dalling's caves are particularly active, and the noise of running water can disturb hibernating bats (Speakman et al. 1991). Chantal's Cave has two entrances, and a noticeable draft through this cave results in variable and low winter temperatures that make the site unsuitable for hibernating bats. As well, Glebe Mine and Harbell's, Dalling's, and Chantal's caves do not have inclined entrances, so that, unlike the other caves, they do not trap cold air and are influenced more by outside temperatures. This is particularly obvious when the maximum and minimum temperatures of the caves are considered.

The difference in the magnitude of the variation in air temperature between September and November and between March and June may be due to cave topography. In caves with an entrance that includes a vertical drop, dense, cold air will flow into the cave during cold weather periods and then remain trapped in the cave during warm weather. Once such a body of cold air is established, it appears to be fairly resistant to change as the above ground air warms. Indeed, none of the New Brunswick study caves reached their maximum temperatures until early September or October. At this time, caves no longer appear to be buffered by the internal body of cold air and therefore experience greater temperature variation.

The body of cold air is not re-established until early February or March, when caves reach their minimum temperatures, and this period is accompanied by a reduction in temperature variation. Similarly, in Nova Scotia, maximum cave temperatures were recorded in September and October and minimum temperatures in January and February (Moseley 2007b); in Indiana, maximum cave temperatures were recorded in September and October and minima between January and March (Richter et al. 1993). These results suggest con- 
siderable similarity in patterns of seasonal cave temperatures across temperate North America.

Bat abundance in the New Brunswick caves studied was negatively correlated with winter temperature variation and the presence of running water in the main passage. In England, Glover and Altringham (2008) found that bat swarming (mating) activity was negatively correlated with the amount of water passing through a cave. Briggler and Prather (2003) found that bats in Arkansas prefer to hibernate in larger caves because these caves have greater buffering capacity. Bat abundance was not correlated with cave length in New Brunswick.

Sandel et al. (2001) found that minimum cave temperature was a significant microclimate predictor of the abundance of bats in Texas hibernacula, but this was not the case in New Brunswick. Briggler and Prather (2003) found that Perimyotis subflavus was significantly more likely to be found in Arkansas caves with higher temperatures $\left(11.4^{\circ} \mathrm{C}\right.$ vs. $\left.10.5^{\circ} \mathrm{C}\right)$, but in New Brunswick we found bat abundance was negatively correlated with increasing average winter dark zone temperature, once non-hibernacula (the two coldest caves) were excluded.

Hibernating at warm temperatures leads to increased energy expenditure but lessens the negative physiological aspects of hibernation (Boyles et al. 2007). It is possible that, in areas with relatively long hibernation periods (like New Brunswick), conserving energy by hibernating at low temperatures is a more effective strategy than reducing the negative physiological aspects of hibernation by roosting at higher temperatures.

The optimal hibernation temperature for Myotis lucifugus has been reported as $2^{\circ} \mathrm{C}$ because metabolic rate is at its lowest at this temperature (Hock 1951; McManus 1974). However, Boyles and McKechnie (2010) argue that the optimal hibernating temperature in environments that are thermally unstable is above the temperature at which the metabolic rate is minimized. Microclimates in hibernacula fluctuate over the winter, and bat energy expenditure is positively correlated with temperature variation (Boyles and McKechnie 2010). $M$. lucifugus incur disproportionately larger energetic costs roosting at temperatures below $2^{\circ} \mathrm{C}$ than above $2^{\circ} \mathrm{C}$ (Boyles and McKechnie 2010). Therefore, to accommodate temperature fluctuations, the optimal hibernation temperature for $M$. lucifugus appears to be a few degrees above $2^{\circ} \mathrm{C}$.

Wilder et al. (2011) suggest that mines are less likely to be affected by white-nose syndrome than caves, perhaps due to differences in microclimate or the population dynamics of bats occupying mines, and data presented by Langwig et al. (2012) indicated that the impacts of white-nose syndrome are greater in warmer, more humid hibernacula. In the current study, mines in New Brunswick were slightly warmer than caves, but it remains unclear whether such sites offer any kind of refuge from white-nose syndrome in the Maritimes.
In conclusion, hibernacula in New Brunswick that support the greatest number of Myotis lucifugus, $M$. septentrionalis, and Perimyotis subflavus show little temperature variation, have average winter dark zone temperatures of $4-5^{\circ} \mathrm{C}$, and have a minimum dark zone temperature no lower than $3.1^{\circ} \mathrm{C}$. New Brunswick caves with these temperature patterns characteristically have a main passage length of $\geq 140 \mathrm{~m}$, do not have running water, and do not have multiple entrances.

Few cave sites in New Brunswick meet these criteria, and winter bat counts appear to be well below estimated summer bat populations. Clearly many bats either hibernate in unknown and inaccessible locations in the province or migrate out of the province annually to locate suitable hibernacula. Such movements may have hastened the arrival of white-nose syndrome in New Brunswick, first documented in the province's largest hibernaculum in March 2011.

\section{Acknowledgements}

We thank Joel Smith, Lynne Burns, Kelly Sparks, Katie Leger, Evan Young, Hurst Ganon, and Fenning McAlpine for invaluable field assistance. We are grateful to Joan Chown, Tony Gilchrist, and David Roberts for allowing us access to their properties. Research funding was provided by the New Brunswick Wildlife Trust Fund, the New Brunswick Department of Natural Resources, and the University of New Brunswick. KV was in receipt of an Orville Erickson Scholarship from the Canadian Wildlife Federation during a portion of the work and offers her thanks for this support.

Documents Cited (marked * in text)

Environment Canada. 2011. National Climate Data and Information Archive, Canadian Climate Normals 19712000, Saint John and Moncton, New Brunswick. http:// www.climate.weatheroffice.gc.ca/climate_normals/result s_e.html?stnID $=6250 \&$ lang $=\mathrm{e} \& \mathrm{dCode}=1 \&$ province $=\mathrm{NB}$ \&provBut $=\&$ month $1=0 \&$ month2 $=12$. (Accessed 8 December 2011).

Statistics Canada. 2005. Land and freshwater area, by province and territory. Summary tables, Statistics Canada. http://www.statcan.gc.ca/tables-tableaux/sum-som/101 /cst01/phys01-eng.htm. (Accessed 10 January 2012).

United States Fish and Wildlife Service. 2009. Recommended procedures to prevent the possible spread of white-nose syndrome. http://whitenosesyndrome.org/topics/decontam ination (Accessed September 11, 2012).

Wilson, Z. 2009. White nose syndrome and bat hibernacula. Bat Conservation International. http://batmanagement.com /wns/wns.html. (Accessed 10 January 2012).

\section{Literature Cited}

Arseneault, S. P., J. Schroeder, D. Berube, and R. Albert. 1997. The caves of southeastern New Brunswick (revised and supplemented). Natural Resources and Energy. Open file 97-7: 1-33.

Blehert, D. S., A. C. Hicks, M. Behr, C. U. Meteyer, B. M. Berlowski-Zier, E. L. Buckles, J. T. H. Coleman, S. R. Darling, A. Gargas, R. Niver, J. C. Okoniewski, R. J. Rudd, and W. B. Stone. 2009. Bat white-nose syndrome: 
an emerging fungal pathogen? Science 323 (5911): 227 227.

Boyles, J. G., M. B. Dunbar, J. J. Storm, and V. Brack, Jr. 2007. Energy availability influences microclimate selection of hibernating bats. Journal of Experimental Biology 210: 4345-4350.

Boyles, J. G., and A. E. McKechnie. 2010. Energy conservation in hibernating endotherms: why "suboptimal" temperatures are optimal. Ecological Modelling 221: 1646-1649.

Briggler, J. T., and J. W. Prather. 2003. Seasonal use and selection of caves by the Eastern Pipistrelle Bat (Pipistrellus subflavus). American Midland Naturalist 149(2): 406412.

Daan, S., and H. J. Wichers. 1968. Habitat selection by bats hibernating in a limestone cave. Zeitschrift für Saugetierkunde 33: 262-287.

Davis, W. H. 1959. Disproportionate sex ratios in hibernating bats. Journal of Mammalogy 40: 16-19.

Davis, D. S., and S. Browne. 1996. The natural history of Nova Scotia. Volume 1: Topics and habitats. Nimbus Publishing, Nova Scotia Museum. 518 pages.

Dwyer, P. D. 1971. Temperature regulation and cave-dwelling in bats: an evolutionary perspective. Mammalia 35: 424455.

Frick, W. F., J. F. Pollock, A. C. Hicks, K. E. Langwig, D. S. Reynolds, G. G. Turner, C. M. Butchkoski, and T. H. Kunz. 2010. An emerging disease causes regional population collapse of a common North American bat species. Science 329: 679-682.

Glover, A. M., and J. D Altringham. 2008. Cave selection and use by swarming bat species. Biological Conservation 141: $1493-1504$.

Griffin, D. R. 1945. Travels of banded cave bats. Journal of Mammalogy 26(1): 15-23.

Guthrie, M. J. 1933. Notes on the seasonal movements and habits of some cave bats. Journal of Mammalogy 14: 1-19.

Hitchcock, H. B. 1949. Hibernation of bats in southeastern Ontario and adjacent Quebec. Canadian Field-Naturalist 63: 47-59.

Hock, R. J. 1951. The metabolic rates and body temperatures of bats. Biological Bulletin 101: 289-299.

Hoyos, M., V. Soler, J. C. Canaveras, S. Sanchez-Moral, and E. Sanz-Rubio. 1998. Microclimate characterization of a karstic cave: human impact on microenvironmental parameters of a prehistoric rock art cave (Candamo Cave, northern Spain). Environmental Geology 33(4): 231-242.

Jurado, V., E. Porca, S. Cuezva, A. Fernandez-Cortes, S. Sanchez-Moral, and C. Saiz-Jimenez. 2010. Fungal outbreak in a show cave. Science of the Total Environment 408: 3632-3638.

Laiz, L., M. Gonzalez-Delvalle, B. Hermosin, A. OrtizMartinez, and C. Saiz-Jimenez. 2003. Isolation of cave bacteria and substrate utilization at different temperatures. Geomicrobiology Journal 20: 479-489.

Langwig, K. E., W. F. Frick, J. T. Bried, A. C. Hicks, T. H. Kunz, and A. M. Kilpatrick. 2012. Sociality, densitydependence and microclimate determine the persistence of populations suffering from a novel fungal disease, whitenose syndrome. Ecology Letters 15: 1050-1057.

McAlpine, D. F. 1976. Howes Cave, New Brunswick. Canadian Caver 8: 28-30.

McAlpine, D. F. 1979. Preliminary investigations on the solution caves of New Brunswick. Journal of the New Brunswick Museum 1979: 99-107.

McAlpine, D. F. 1982. Map surveys of New Brunswick solution caves. Canadian Caver 14: 26-31.
McAlpine, D. F. 1983. Status and conservation of solution caves in New Brunswick. New Brunswick Museum Publications in Natural Science No. 1. 28 pages.

McAlpine, D. F., K. J. Vanderwolf, G. J. Forbes, and D. Malloch. 2011. Consumption of bats (Myotis spp.) by Raccoons (Procyon lotor) during an outbreak of white-nose syndrome in New Brunswick, Canada: implications for estimates of bat mortality. Canadian Field-Naturalist 125: 257260.

McManus, J. J. 1974. Activity and thermal preference of the little brown bat, Myotis lucifugus, during hibernation. Journal of Mammalogy 55: 844-846.

McNabb, K. 1974. The behavior of temperate cave bats in a subtropical environment. Ecology 55: 943-958.

Meretsky, V. J., V. Brack Jr., T. C. Carter, R. Clawson, R. R. Currie, T. A. Hemberger, C. J. Herzog, A. C. Hicks, J. A. Kath, J. R. MacGregor, R. A. King, and D. H. Good. 2010. Digital photography improves consistency and accuracy of bat counts in hibernacula. Journal of Wildlife Management 74(1): 166-173.

Moseley, M. 2007a. Records of bats (Chiroptera) at caves and mines in Nova Scotia. Curatorial Report no. 99, Nova Scotia Museum, Halifax, Nova Scotia. 21 pages.

Moseley, M. 2007b. Acadian biospeleology: composition and ecology of cave fauna of Nova Scotia and southern New Brunswick, Canada. International Journal of Speleology 36(1): 1-21.

Neubaum, D. J., T. J. O'Shea, and K. R. Wilson. 2006. Autumn migration and selection of rock crevices as hibernacula by big brown bats in Colorado. Journal of Mammalogy 87(3): 470-479.

Richter, A. R., S. R. Humphrey, J. B. Cope, and V. Brack, Jr. 1993. Modified cave entrances: thermal effect on body mass and resulting decline of endangered Indiana bats (Myotis sodalis). Conservation Biology 7(2): 407-415.

Sandel, J. K., G. R. Benatar, K. M. Burke, C. W. Walker, T. E. Lacher Jr., and R. L. Honeycutt. 2001. Use and selection of winter hibernacula by the Eastern Pipistrelle (Pipistrellus subflavus) in Texas. Journal of Mammalogy 82(1): 173-178.

Scott, F., and A. J. Hebda. 2004. Annotated list of the mammals of Nova Scotia. Proceedings of the Nova Scotia Institute of Science 42(2): 189-208.

Speakman, J. R., P. I. Webb, and P. A. Racey. 1991. Effects of disturbance on the energy expenditure of hibernating bats. Journal of Applied Ecology 28: 1087-1104.

Thomas, D. W. 1995. Hibernating bats are sensitive to nontactile human disturbance. Journal of Mammalogy 76: 940946.

Turner, G.R., and D. M. Reeder. 2009. Update of white-nose syndrome in bats. Bat Research News 50: 47-53.

Wilder, A. P., W. F. Frick, K. E. Langwig, and T. H. Kunz. 2011. Risk factors associated with mortality from whitenose syndrome among hibernating bat colonies. Biology Letters 7: 950-953.

Willis, C. K. R., J. W. Jameson, P. A. Faure, J. G. Boyles, V. Brack, Jr., and T. H. Cervone. 2009. Thermocron iButton and iBBat temperature dataloggers emit ultrasound. Journal of Comparative Physiology B 179: 867-874.

Zelazny, V. F. 2007. Our landscape heritage: the story of ecological land classification in New Brunswick. Second edition. New Brunswick Department of Natural Resources, Fredericton, New Brunswick. 359 pages.

Received 1 February 2012

Accepted 11 May 2012 